\title{
A Study on the Teaching of Professional-Oriented English Writing in Applied-Type University Based on I Write 2.0
}

\author{
Feipeng Li, Liyan Xiao \\ College of Foreign Languages Education and International Business, Baoding University, Baoding, China \\ Email: 1fp19801104@163.com
}

How to cite this paper: Li, F. P., \& Xiao, L. Y. (2020). A Study on the Teaching of Professional-Oriented English Writing in Applied-Type University Based on I Write 2.0. Creative Education, 11, 1720-1729.

https://doi.org/10.4236/ce.2020.119125

Received: August 4, 2020

Accepted: September 18, 2020

Published: September 21, 2020

Copyright $\odot 2020$ by author(s) and Scientific Research Publishing Inc. This work is licensed under the Creative Commons Attribution International License (CC BY 4.0).

http://creativecommons.org/licenses/by/4.0/

\begin{abstract}
As one of the indispensable public compulsory courses, College English is required to be practical application-oriented and cultivation of students' application ability-focused. English Writing, which is an essential component of English practical abilities, needs more attentions and explorations by college English teachers and researchers, particularly in applied-type universities. By experimental studies, this paper aimed to contrast the differences of English comprehensive ability and English writing ability under the teaching mode combining iWrite assistance and major orientation and the teaching mode with traditional approaches. It was found through research that by means of iWrite 2.0 students could achieve measurable progress both in professional-oriented English writing skills and English comprehensive abilities. Meanwhile, students' autonomous learning ability was also significantly promoted. Then, with data collection and analysis, the writer deeply discussed and explored the causes of what had been found in the research. The limitations of the research and the conclusion were also expounded in the final part of this paper.
\end{abstract}

\section{Keywords}

English Writing, Professional Orientation, Application, iWrite 2.0

\section{Introduction}

College English, an integral part of higher learning, is a required basic course for undergraduate students. It is a systematic whole, incorporating different teaching models and approaches. College English Curriculum Requirements points out that College English has the quality of instrumentalism and humanism. Its instrumentalism can be embodied in ESP that students could acquire the abili- 
ties to communicate in the fields of academy and occupation by learning English for academic purposes and professional English. In College English Curriculum Requirements, the demands for undergraduate college English teaching are set at three levels, i.e., basic requirements, intermediate requirements, and advanced requirements. As to the part of writing in intermediate requirements, students should be able to express, by and large, personal views on general topics, compose English abstracts for thesis in their own specialization, and write short English papers on topics in their field. The teachers in applied-type universities and colleges should attach more importance to the teaching of professional-oriented English writing. Meanwhile, the automated teaching and evaluation system iWrite 2.0 can immediately evaluate students' compositions from four dimensions (language, content, organization, and mechanics) and highlight their errors and error types. This research explores the effectiveness of the combination of professional-oriented college English writing teaching and the application of iWrite system so as to provide a more efficient approach to the teaching of English writing in applied-typed universities and colleges.

\section{Literature Review}

Writing is an advanced cognitive activity and comprehensive reflection of logical thinking ability and language applied ability (Swain, 1995). The study on the second language writing overseas expanded enormously in the 1980s, and formed its own theoretical system, research subjects, research methods and research team, gradually developing into an independent discipline with definite range of study (Kroll, 2003). Great progress in foreign language writing in China has been made for the past dozen years. One of the prominent characteristics is the diversity of research methods with more and more empirical studies especially the combination of quantitative research and qualitative research. College English Curriculum Requirements points out that college English should not only emphasize the ability of English for general purpose, but it also needs to further strengthen their communication ability of academic and vocational English. Many scholars and teachers have done a lot of research on English writing based on ESP or professional or vocational English. Based on project-oriented curriculum model and English levels of the students specializing in ESP of local vocational colleges, Liu (2012) probed into building a construction-oriented applicable English writing approach framework. Tang (2013) conducted a survey for requirements from employers, students and teachers, and designed an innovative English teaching mode relating to specialty.

Automated Essay Scoring or Automated Writing Evaluation originally appeared in the middle of the 1960s. Page, professor in Duke university, developed Page Essay Grade (PEG). With the evolution of information technology, an increasing number of scholars have been doing research on English writing automated feedback system in recent two decades. The widely-used automated feedback systems abroad are Criterion-E-rater developed by ETS (Bursein \& Marcu, 2003), Intellimetric, and My Access! by Vantage Learning (Eliot, 2004). The 
evaluation systems mentioned above have definitely eased teachers' burden and raised the evaluating efficiency. With the limitation of sample input, however, the reliability and validity of evaluation require further technical improvement. IWrite 2.0, developed based on the advanced linguistic processing concept and the needs of daily teaching, has enormously powerful advantages with a series of intelligent functions. The research on English writing automated evaluation system in China focuses on the development and application of English writing automated system software. Li (2018) made a multi-perspective comparison between the manual evaluation and iWrite 2.0 evaluation, by which the evaluation reliability of iWrite 2.0 was demonstrated. He and Gong (2017) argued that several functions of iWrite 2.0 needs to be improved including its annotation of error types, comment accuracy and function of plagiarism detection.

\section{Methodology}

\subsection{Research Questions}

In order to find out a more effective feedback way for college English writing and a more valid approach to promoting students' English application ability, the study explores three research questions listed below:

1) To investigate whether the teaching of professional-oriented English writing based on iWrite 2.0 can affect students' writing ability.

2) To investigate whether the teaching of professional-oriented English writing based on iWrite 2.0 can affect students' comprehensive ability.

3) To investigate whether the use of iWrite 2.0 can improve students' autonomous learning ability.

\subsection{Subjects}

The researchers selected Baoding University in Hebei province which is a typical local application-oriented undergraduate university as the survey object. Two hundred and nine non-English major undergraduates of Grade 2017 from different departments with the ratio of male to female basically balanced were selected as the research subjects to participate in the pre-test, post-test, experimental training practice, and questionnaire survey. Totally, two hundred and eight subjects participated the pre-test and post-test. The research subjects refer to four different majors and four experimental classes, which is shown in Table 1.

\subsection{Instruments}

The research instruments employed in this study include standardized test paper, questionnaire, iWrite 2.0, and statistical software.

Table 1. Basic situation of subjects.

\begin{tabular}{ccccc}
\hline Major & Maths & History & Chemistry & Chinese \\
\hline Number & 49 & 56 & 58 & 45 \\
\hline
\end{tabular}


The test paper is composed of reading comprehension, gap filling, cloze and writing. The first three parts are chosen from CET 4 of June and December in 2017, all of which are objective questions. Two writing tasks are designed in Part four, including one general essay in no less than 120 words and one essay concerning students' majors. The questionnaire is designed mainly to investigate the students' attitude toward English writing under the new teaching ideas and teaching mode, the improvement of their English writing ability and the change of their autonomous learning ability.

\subsection{Procedures}

The paper aims to contrast the differences in students' English comprehensive and writing levels through experimental research. The procedures mainly refer to pre-test, implementation of teaching and writing practice, post-test and questionnaire surveys.

\subsubsection{Pre-Test}

Before the experiment, all the subjects in the four experimental classes were required to take a pre-test. In order to test students' writing abilities both in EGP and ESP, two tasks were designed in the part of writing: a normal English essay with a definite topic and another related to students' major knowledge. The part of compositions was scored by three experienced raters and iWrite 2.0. so as to guarantee the reliability and objectivity of the results.

\subsubsection{Implementation of Teaching}

In the first term, the subjects were offered college English integrated course and visual-audio-oral course. The objective of this term was to further consolidate and improve students' basic English skills, laying a firm foundation for the study of next stage. In the second term, the teachers appropriately reduced the class hours of integrated course and increased the proportion of writing class and ESP class according to the schedule made by the project team. The third term focused on the teaching and practice of professional-oriented writing based on the assistance of iWrite 2.0 with a smaller proportion of integrated class.

In the third term, the teaching model of college English autonomous writing lasted 15 weeks. Every subject was required to submit a composition to iWrite 2.0 writing center each week as requested by teachers. Due to one of the powerful functions of iWrite 2.0, students were allowed and encouraged to revise and submit their compositions repeatedly. The humanization of iWrite is reflected in its intelligent function that not only the type of errors are classified and highlighted in red, but also modify advice is offered in the automated feedback. Meanwhile, teachers checked the statistics of error types provided by the system and mastered the students' performances including average scores, plagiarism and other aspects.

\subsubsection{Post-Test}

At the end of the experiment, all the subjects in experimental classes were re- 
quired to take a post-test with the same question types and requirements as pre-test paper. The part of compositions was also scored by two experienced raters and iWrite 2.0 .

\subsubsection{Questionnaire}

A total of 209copies of questionnaires were distributed and 205 valid were collected. Questions 1 to 4 were mainly to investigate whether students made improvement in writing including language, content and structure; Questions 5 to 9 focused on investigating students' change in the attitude towards English writing and autonomous learning capacities.

\section{Result and Discussion}

Based on the data collected, the research results and discussion refer to the analysis of the effect of professional-oriented writing teaching assisted by iWrite 2.0 system on students' autonomous writing ability, students' attitude toward the teaching model of writing applied in the research process, students' writing scores and comprehensive scores.

\subsection{Result and Discussion about Students' Autonomous Writing Ability}

The teachers assigned a writing task with specific demands to students each week lasting consecutive 12 weeks in the third term, the topic of which was closely connected to their majors. Students submitted their compositions to iWrite 2.0 writing center within the allotted time. They could revise their compositions according to the feedback from the system and resubmitted repeatedly until they were satisfied with their essays. The statistics of students' writing training situation are shown in Table 2 below.

Table 2. Students' situation of writing training.

\begin{tabular}{cccccc}
\hline Number & $\begin{array}{c}\text { Minimum } \\
\text { frequency }\end{array}$ & $\begin{array}{c}\text { Maximum } \\
\text { frequency }\end{array}$ & $\begin{array}{c}\text { Average } \\
\text { frequency }\end{array}$ & $\begin{array}{c}\text { Average } \\
\text { words }\end{array}$ & $\begin{array}{c}\text { Average } \\
\text { scores }\end{array}$ \\
\hline Task1 & 1 & 3 & 2 & 111 & 55 \\
Task2 & 1 & 6 & 3 & 124 & 58 \\
Task3 & 2 & 7 & 4 & 128 & 63 \\
Task4 & 2 & 8 & 130 & 68 \\
Task5 & 2 & 8 & 4 & 132 & 68 \\
Task6 & 3 & 10 & 5 & 135 & 71 \\
Task7 & 3 & 11 & 5 & 136 & 72 \\
Task8 & 4 & 11 & 6 & 138 & 72 \\
Task9 & 4 & 12 & 7 & 140 & 76 \\
Task10 & 4 & 13 & 7 & 142 & 79 \\
Task11 & 5 & 13 & 7 & 145 & 79 \\
Task12 & 5 & 15 & 7 & 72 & 76 \\
\hline
\end{tabular}


As is shown in Table 2, the maximum of submitting frequency, the minimum of submitting frequency, the average submitting frequency and average scores are on the rise from the first writing task to the final. Meanwhile, what can be seen in Table 3 is that totally $86.8 \%$ students agree or strongly agree that their interest in English writing has been developed by means of iWrite 2.0, 95.1\% students agree or strongly agree that they have got more confidence in writing, which indicates students have gradually adapted to the system and cultivated more positive attitude to English writing. One of the most important reasons for their improvements may be that they could proactively revise and perfect their compositions in the light of the feedback or suggestions provided by the system. For example, in the eighth writing task, a subject from chemistry class 1 totally submitted her revised manuscript for twelve times. By tracking and analyzing her eighth task of compositions from edition 1 to 12 , researchers found that all the measurement dimensions of the 12 compositions are in a trend of progress. It indicates that the subjects could revise their compositions with a positive and voluntary attitude, not just passively coping with the assignments given by teachers. What's more, the average number of words for each composition (the number of words of the final-submitted edition) are on the increase all the time, from average 111 words for the first composition to average 145 words for the twelfth composition.

The statistics listed in Table 2 and Table 3 shows that the writing system has efficiently aroused students' interest, initiative and autonomy in English writing, guiding students to change from the statement of "want me to write" to "want to write". Designed based on deep research on the teaching process of college English writing, iWrite 2.0 realizes automated intelligent evaluation from four dimensions including language, contents, structure and technical specifications. The design concept of the system embodies the idea of process-oriented approach, which can validly improve students' writing proficiency, develop their attitudes towards English writing and increase their interest and confidence in English writing. The application of iWrite 2.0, to a great degree, contributes to the sustainable development of students' writing desire and ability.

\subsection{Result and Discussion about Students' Writing Abilities}

The scores of compositions in the pre-test and post-test are given by iWrite 2.0. Meanwhile, the measurement dimensions including language, contents, technical specifications, structure etc. are also provided by the system. The result of Paired t test (see Table 4) shows that there is significant difference between pre-test writing scores and post-test writing scores $(\mathrm{t}=-6.516, p<0.05)$ : students' writing grades of pre-test are significantly lower than those of post-test $(\mathrm{MD}=-1.07)$.

There exist significant differences in four dimensions except STTR between pre-test and post-test $(t$ word number $=-3.617, t$ word length $=-2.612, t$ sentence length $=-2.566, t$ clause number $=-3.718, p<0.05)$ : the measured values 
of pre-test are significantly lower than that of post-test $(M D$ word number $=$ $-6.63, M D$ word length $=-0.061, M D$ sentence length $=-1.07, M D$ clause number $=-1.16)$ (see Table 5).

It can be seen from the result of questionnaire survey (see Table 3 ) that $94.1 \%$ students agree or strongly agree that they have reduced technical errors in writing, $98.5 \%$ students agree or strongly agree that they have made less mistakes in grammar than before, and all the students think that their English writing efficiency has been greatly promoted with the assistance of iWrite 2.0.

Table 3. Students' feedback to the use of iWrite 2.0.

\begin{tabular}{|c|c|c|c|c|c|}
\hline \multirow[b]{2}{*}{ Questions } & \multicolumn{5}{|c|}{ Total $(\mathrm{N}=205)$} \\
\hline & Strongly agree & Agree & $\begin{array}{l}\text { Not } \\
\text { sure }\end{array}$ & Disagree & $\begin{array}{l}\text { Strongly } \\
\text { disagree }\end{array}$ \\
\hline 1) Reduce technical errors & 81 & 102 & 16 & 6 & 0 \\
\hline $\begin{array}{l}\text { 2) Reduce grammatical } \\
\text { errors }\end{array}$ & 117 & 85 & 3 & 0 & 0 \\
\hline 3) Improve the structure & 81 & 94 & 25 & 5 & 0 \\
\hline $\begin{array}{l}\text { 4) Enhance writing } \\
\text { efficiency }\end{array}$ & 201 & 4 & 0 & 0 & 0 \\
\hline $\begin{array}{l}\text { 5) Develop interest in } \\
\text { writing }\end{array}$ & 106 & 72 & 15 & 12 & 0 \\
\hline $\begin{array}{l}\text { 6) Develop motivation } \\
\text { in writing }\end{array}$ & 79 & 106 & 16 & 4 & 0 \\
\hline $\begin{array}{l}\text { 7) Develop confidence } \\
\text { in writing }\end{array}$ & 113 & 82 & 10 & 0 & 0 \\
\hline $\begin{array}{l}\text { 8) Improve autonomous } \\
\text { learning ability }\end{array}$ & 89 & 92 & 18 & 6 & 0 \\
\hline $\begin{array}{l}\text { 9) Improve reflection on } \\
\text { writing }\end{array}$ & 66 & 101 & 25 & 13 & 0 \\
\hline
\end{tabular}

Table 4. Difference of writing scores between pre-test and post-test.

\begin{tabular}{ccccccc}
\hline \multicolumn{2}{c}{ Pre-test } & \multicolumn{3}{c}{ Post-test } & \multicolumn{3}{c}{ Comparison test } \\
\hline$M$ & $S D$ & $M$ & $S D$ & $M D$ & $t$ & Sig. \\
5.28 & 1.969 & 6.36 & 2.16 & -1.07 & -6.516 & 0.000 \\
\hline
\end{tabular}

Table 5. Difference of dimensions values between pre-test and post-test.

\begin{tabular}{cccccccc}
\hline & \multicolumn{2}{c}{ Pre-test } & \multicolumn{2}{c}{ Post-test } & \multicolumn{2}{c}{ Comparison test } \\
\cline { 2 - 7 } & $M$ & $S D$ & $M$ & $S D$ & $M D$ & $t$ & Sig. \\
\hline Word number & 117.68 & 20.87 & 141.39 & 22.15 & -6.63 & -3.617 & 0.000 \\
word length & 4.36 & 0.29 & 4.42 & 0.29 & -0.061 & -2.612 & 0.010 \\
sentence length & 15.19 & 6.30 & 16.26 & 4.87 & -1.07 & -2.566 & 0.011 \\
clause number & 8.42 & 3.32 & 9.58 & 3.83 & -1.16 & -3.718 & 0.000 \\
\hline
\end{tabular}


The statistics listed above indicate that the writing ability of a majority of students in the experimental classes has obviously improved. Two factors can account for student's progress in writing. Firstly, the adjustment of curriculum increases the writing class hours, so teachers manage to spend relatively sufficient time in the teaching of writing knowledge and skills, particularly in the instruction of major-related expressions and writing technology. Secondly, the teaching model in experimental classes integrates machine evaluation and teacher evaluation and improves feedback with intelligent system assessment. iWrite 2.0 provides diversified and visual analysis statistics of composition manuscripts, ranging from analysis on error types with their proportions in mistakes made by students to STTR, lexical difficulties, and complexity of sentences. The powerful and humanistic functions of the system can effectively benefit students' writing levels and their interest and desires in English writing.

\subsection{Result and Discussion about Students' Comprehensive Scores}

The result of Paired $t$ test shows that there are significant differences in comprehensive scores between pre-test and post-test ( $\mathrm{t}$ reading comprehension $=$ $-3.791, t$ cloze $=-7.938, t$ gap filling $=-10.077, p<0.05)$ : the scores of each type of question in pre-test are significantly lower than that in post-test ( $M D$ reading comprehension $=-1.55, M D$ cloze $=-1.55, M D$ gap filling $=-2.69)($ see Table 6).

Because of the interaction of language input and output, writing course can not only improve students' writing ability, but also can promote the advancement of students' overall language abilities. The statistics in Table 5 indicate that in spite of the reduction of integrated English class hours in curriculum system applied in experimental class, writing practice provided students opportunities for language output training. Students constantly reflected on their own language behavior in writing practice, promoted the accuracy and validity of their language expression, thus achieving significant progress in comprehensive ability of a majority of students.

\section{Conclusion}

The running principle of application-oriented colleges and universities is to cultivate applied talents with professional skills and abilities. English course in such type of universities is required to be carried out closely around the aim of cultivation. The instrumentalism of college English can be embodied in its combination with professional knowledge and skills, better serving students' development of majors. The teaching of professional-oriented English writing has realized the dynamic integration of college English and the demands for major development, which also coincides with the demands for writing in College English Curriculum Requirements. With the powerful functions of iWrite 2.0 which provides automated feedback and revising suggestions including language, contents, structures and technical specifications, students' writing abilities, initiative 
Table 6. Difference of comprehensive scores between pre-test and post-test.

\begin{tabular}{cccccccc}
\hline & \multicolumn{2}{c}{ Pre-test } & \multicolumn{2}{c}{ Post-test } & \multicolumn{3}{c}{ Comparison test } \\
\cline { 2 - 8 } & $M$ & $S D$ & $M$ & $S D$ & $M D$ & $t$ & Sig. \\
\hline Reading & 15.01 & 4.81 & 141.39 & 22.15 & -1.55 & -3.791 & 0.000 \\
Cloze & 9.42 & 3.85 & 12.09 & 4.65 & -1.55 & -7.938 & 0.000 \\
Gap filling & 5.08 & 1.93 & 6.62 & 2.11 & -2.69 & -10.077 & 0.000 \\
\hline
\end{tabular}

and enthusiasm are significantly promoted. Meanwhile, the automated system allows students' to submit their compositions repeatedly, so students can revise the compositions according to the feedback and advice offered by the intelligent system and perfect their compositions step by step, which felicitates development of students' autonomous learning abilities, thus contributing to both their English learning and profession learning. What's more, the teaching of professional-oriented English writing based on iWrite 2.0 enhances students' comprehensive abilities of English. Therefore, college English curriculum system can be appropriately adjusted like increasing the teaching and training hours of professional-oriented English writing in order to meet the needs of profession development. Limited by circumstances and time, this study hasn't implemented stricter test on control classes. More influencing factors should be taken into consideration and further studies need to be carried out around this project. It may become an inexorable trend that the assistance of automated intelligent feedback system will be increasingly incorporated into college English teaching and practice.

\section{Funding}

This research was supported by Project: English Teaching Reform Research and Practice Project of Hebei Colleges and Universities, 2018 (Hebei Education Department Official Letter [2018] 53). Project number: 2018YYGJ059.

\section{Conflicts of Interest}

The authors declare no conflicts of interest regarding the publication of this paper.

\section{References}

Bursein, J., \& Marcu, D. (2003). Developing Technology for Automated Evaluation of Discourse Structure in Student Essays. In M. D. Shermis \& J. C. Burstein (Eds.), Automated Essay Scoring: A Cross-disciplinary Perspective (pp. 209-230). Hillsdale, NJ: Lawrence Erlbaum.

Eliot, R. (2004). The Study of Second Language Acquisition. Oxford: Oxford University Press.

He, Z. C., \& Gong, Y. Z. (2017). Case Study of Application of iWrite English Writing Evaluation System 2.0. Journal of Chengdu Aeronautic Polytechnic, No. 3, 29-32.

Kroll, B. (2003). Exploring the Dynamics of Second Language Writing. Cambridge: Cam- 
bridge University Press. https://doi.org/10.1017/CBO9781139524810

Li, Y. L., \& Tian, X. C. (2018). An Empirical Research into the Reliability of iWrite 2.0. Modern Educational Technology, No. 2, 75-80.

Liu, G. Q. (2012). Applicable English Writing Teaching Approach Framework Use in ESP Programmes. Journal of Guilin Normal College, No. 4, 128-132.

Swain, M. (1995). Three Functions of Output in Second Language Learning. In G. Cook, \& B. Seidlhofer (Eds.), Principle and Practice in Applied Linguistics: Studies in Honour of H. G. Widdowson (pp. 125-144). Oxford: Oxford University Press.

Tang, Y., Feng, J., \& Thomas, L. (2013). Design and Practice of the Specialty-Oriented English Teaching in Engineering Colleges. Research in Higher Education in Engineering, No. 4, 185-188. 